p-ISSN 2089-9858

e-ISSN 2502-3314

\title{
Pengaruh Air Kelapa (Cocos nucivera) dan Bokashi Kirinyuh (Chromolaena odorata) terhadap Pertumbuhan Tanaman Sawi (Brassica juncea L.)
}

\section{The Effect of Coconut Water (Cocos nucivera) and Bokashi of Kirinyuh (Chromolaena odorata) on the Growth of Mustard Greens (Brassica juncea L.)}

\author{
Sumardin $^{1}$, Andi Bahrun ${ }^{2 *}$, dan Norma Arif ${ }^{2}$ \\ ${ }^{1}$ Program Studi Magister Agronomi Pascasarjana Universitas Halu Oleo \\ 2 Jurusan Agroteknologi Fakultas Pertanian Universitas Halu Oleo
}

Diterima: 08 Januari 2021/Disetujui: 25 September 2021

\begin{abstract}
ABSTRAK
Produksi tanaman sawi (Brassica juncea L.) rendah akibat kesuburan tanah yang rendah. Penggunaan bokashi kirinyuh dan air kelapa muda mungkin dapat memperbaiki kesuburan tanah dan dapat meningkat pertumbuhan dan produksi tanaman sawi. Penelitian ini bertujuan untuk mengetahui pengaruh penyiraman air kelapa (Cocos nucivera) dan pemberian dosis bokasi krinyuh (Chromolaena odorata) terhadap pertumbuhan tanaman sawi (Brassica juncea L.). Penelitian ini disusun berdasarkan Rancangan Acak Kelompok (RAK) dalam pola faktorial yang terdiri dari 2 faktor. Faktor pertama adalah air kelapa muda yang terdiri atas 4 taraf: tanpa air kelapa (A0), air kelapa muda 100 ml per tanaman (A1), $150 \mathrm{ml}$ per tanaman (A2), $200 \mathrm{ml}$ per tanaman (A3). Faktor kedua adalah bokasi krinyuh yang terdiri atas 4 taraf yaitu tanpa bokasi kirinyuh (K0), 7,5 g bokasi kirinyuh/kg tanah (K1), $10 \mathrm{~g}$ bokasi kirinyuh/kg tanah (K2), 12,5 g bokasi kirinyuh/kg tanah (K3). Hasil penelitian menunjukan bahwa air kelapa berpengaruh terhadap tinggi tanaman, jumlah daun dan luas daun tanaman sawi. Perlakuan air kelapa $200 \mathrm{ml} /$ tanaman meningkatkan tinggi tanaman, jumlah daun dan luas daun masing-masing 30.88\%, 27,59\% dan 56.96\% dibanding dengan kontrol pada umur 28 hari setelah tanam. Bokashi kirinyuh berpengaruh terhadap tinggi tanaman, jumlah daun, luas daun, berat segar dan kering akar serta berat segar dan berat kering tanaman sawi. Perlakuan $12,5 \mathrm{~g}$ bokashi kirinyuh $\mathrm{kg}^{-1}$ tanah meningkatkan tinggi tanaman, jumlah daun, luas daun, berat segar akar, berat kering akar, berat segar tanaman dan berat kering tanaman sawi masingmasing $40.63 \%$, 30,39, 74.91\%, 311.22\%, 325.93\%, 390.10\% dan $224.17 \%$ dibanding dengan kontrol pada umur 28 hari setelah tanam.
\end{abstract}

Kata Kunci: Air kelapa muda, bokasi; krinyuh, pertumbuhan; tanaman sawi.

\section{ABSTRACT}

Yield of mustard plant (Brassica juncea L.) is low due to low soil fertility. The use of coconut water and bokashi of kirinyuh may improve soil fertility, increase the growth and yield of mustard greens. This research aims to determine the effect of coconut water (Cocos nucivera) and bokashi of kirinyuh (Chromolena odorata) on growth of mustard greens. This research was arranged based on a Randomized Block Design (RBD) in a factorial pattern consisted of two factors. The first factor is coconut water consisted of 4 levels: without coconut water (A0), $100 \mathrm{ml} / \mathrm{plant}$ of coconut water (A1), $150 \mathrm{ml} / \mathrm{plant}$ of coconut water (A2), and $200 \mathrm{ml} / \mathrm{plant}$ of coconut water (A3). The second factor is the organic fertilizer of krinyuh consisted of 4 levels: without kirinyuh (K0), 7,5 g of bokashi kirinyuh/kg soil (K1), $10 \mathrm{~g}$ of bokashi kirinyuh/kg soil (K2), and 12,5 g of bokashi kirinyuh/kg soil (K3). This research shows that there was not a significant effect on the interaction between coconut water and bokashi of kirinyuh on the growth of mustard greens. The use of coconut water had a significantly effect on plant height, number of leaves and leaf area. The use of $200 \mathrm{ml} / \mathrm{plant}$ of coconut water increased plant height, number of leaves and leaf area by 30.88\%, 27,59\% dan 56.96\%, respectively, compared to control at 28 days after planting. Bokashi of krinyuh had a significant effect on plant height, number of leaves, leaf area, root fresh weight, root dry weight, shoot fresh weight and shoot dry weight by 40.63\%, 30,39, 74.91\%, $311.22 \%, 325.93 \%, 390.10 \%$ dan $224.17 \%$, respectively, compared to control at 28 days after planting.

Keywords: Coconut water; bokashi; growth; kirinyuh; mustard greens.

\footnotetext{
*Penulis untuk korespondensi, E-mail : andibahrun7@gmail.com
} 


\section{PENDAHULUAN}

Tanaman Sawi (Brassica juncea L) merupakan salah satu jenis sayuran famili kubiskubisan (Brassicaceae) yang berasal dari negeri China. Sawi masuk ke Indonesia sekitar abad ke-17, sayuran ini sudah cukup populer dan diminati di kalangan masyarakat (Darmawan, 2009). Tanaman Sawi rasanya enak serta mempunyai kandungan gizi yang dibutuhkan tubuh manusia seperti energi, protein, lemak, karbohidrat, serat, Fosfor, zat Besi, Natrium, Kalium dan sumber vitamin A. Kandungan gizi serta rasanya yang enak, membuat sawi menjadi salah satu produk pertanian yang diminati masyarakat, sehingga mempunyai potensi serta nilai komersial tinggi (Rukmana, 2005).

Permintaan terhadap tanaman sawi selalu meningkat seiring dengan bertambahnya jumlah penduduk dan kesadaran terhadap menu makanan yang sehat dan bergizi (Haryanto et al. 2006). Meningkatnya permintaan sawi ini ternyata tidak diikuti dengan peningkatan produksi.Berdasarkan data Badan Pusat Statistik (BPS, 2019), produksi sawi di Sulawesi Tenggara (Sultra) dalam dua tahun terakhir mengalami penurunan. Tercatat pada tahun 2018 produksi sawi $1.047,5$ ton dan pada tahun 2019 produksi sawi mencapai 1.000,9 ton dengan penurunan produksi sebesar 46.6 ton.

Penurunan produksi sawi tersebut diduga disebabkan oleh beberapa faktor yang diantaranya adalah rendahnya produktivitas lahan yang digunakan dalam pembudidayaan tanaman sawi. Diketahui bahwa lahan pertanian Sultra didominasi oleh jenis tanah Ultisol. Tanah ultisol merupakan salah satu jenis tanah marginal dengan sifat antara lain memiliki tingkat kemasaman tanah tinggi $(\mathrm{pH}$ rendah), kandungan unsur hara makro seperti $\mathrm{N}, \mathrm{P}$, $\mathrm{K}$ rendah, kapasitas tukar kation (KTK) rendah, kadar bahan organik rendah, dan potensi kelarutan unsur hara mikro seperti $\mathrm{Al}, \mathrm{Fe}$, dan $\mathrm{Mn}$ yang dapat meracuni tanaman cukup tinggi. Untuk memperoleh hasil maksimal pada tanah ultisol maka diperlukan input teknologi berupa pemupukan yang bertujuan untuk mencukupi kebutuhan hara tanaman.

Pupuk organik merupakan bahan pembenah tanah yang paling baik dan alami dari pada bahan pembenah buatan/sintesis.Pada umumnya pupuk organik mengandung hara makro $\mathrm{N}, \mathrm{P}, \mathrm{K}$ rendah tetapi mengandung hara mikro dalam jumlah cukup yang sangat diperlukan untuk pertumbuhan tanaman.Rendahnya penggunaan pupuk organik, mendorong harus adanya pengembangan produk pupuk organik. Dari beberapa bahan baku pembuatan pupuk organik yang ada, yang digunakan pada tanah ultisol yang memiliki potensi yang dapat dimanfaatkan baik dari ketersediaan maupun harga bahan bakunya yang terjangkau adalah penggunaan pupuk cair air kelapa dan pupuk bokasi krinyuh.

Pupuk organik cair merupakan pupuk yang sebagian besar atau seluruhnya terdiri atas bahan organik yang berasal dari tanaman atau hewan. Pupuk organik cair sangat sesuai diberikan pada tanaman sawi.Karena tanaman sawi merupakan tanaman yang dipanen daunnya sehingga penggunaan pupuk cair dapat dengan mudah diserap oleh tanaman sehingga memacu pertumbuhan daun. Salah satu bahan yang dapat dimanfaatkan sebagai pupuk organik cair adalah air kelapa. Air kelapa merupakan salah satu produk tanaman yang dapat dimanfaatkan untuk meningkatkan kesuburan dan pertumbuhan vegetatif tanaman .Air kelapa selain mengandung mineral juga mengandung hormon sitokinin, fosfor dan kinetin yang berfungsi mempergiat (mempercepat) pembelahan sel dan mempunyai pengaruh terhadap perkecambahan dan pertumbuhan.Air kelapa mengandung komposisi kimia yang unik yang terdiri dari mineral, vitamin, gula, asam amino, dan fitohormon yang memiliki efek signifikan terhadap pertumbuhan tanaman Winarto et al. (2015). Selain mengandung vitamin dan mineral, air kelapa muda mengandung 3 hormon giberelin, auksin dan sitokinin yang berperan dalam pertumbuhan tanaman.Air kelapa memberikan pengaruh baik terhadap tinggi dan jumlah daun sawi (Tiwery, 2014).

Ketersediaan hara tanaman selain diupayakan melalui penggunaan pupuk cair, juga dapat dilakukan dengan penggunaan pupuk organik bokasi krinyuh karena dapat menjadi solusi untuk memperbaiki struktur tanah dan mendorong perkembangan populasi mikroorganisme tanah. Bahan organik berperan penting dalam menentukan kemampuan tanah untuk mendukung pertumbuhan tanaman, memperbaiki struktur tanah, meningkatkan kemampuan tanah memegang air, meningkatkan pori-pori tanah dan memperbaiki media perkembangan mikroba tanah. Bokashi mengandung mikroorganisma tanah efektif sebagai decomposer yang dapat mempercepat proses dekomposisi bahan organic dalam tanah, sehingga dapat meningkatkan ketersediaan unsur hara $\mathrm{N}, \mathrm{P}$ dan K bagi tanaman (Wang et al. 2012; Kaya, 2013). Salah satu jenis tanaman yang potensial yang 
dijadikan pupuk bokashi adalah kirinyuh. Kirinyu berpotensi sebagai sumber pupuk $\mathrm{N}$ dan $\mathrm{P}$ dengan kandungan masing-masing sebesar 3,04\% dan $0,29 \%$, karena tumbuhan ini memiliki kualitas yang tinggi dalam melepaskan unsur hara dengan relative cepat (Maftu'ah, 2005), sedangkan Jumila (2005) menyatakan bahwa komposisi hara kirinyuh memiliki $2.42 \% \mathrm{~N}, 0.26 \% \mathrm{P}$ 0,51\%, 50.40\% C dan $20.82 \% \mathrm{C} / \mathrm{N}$. Pemberian kirinyuh berperan penting dalam meningkatkan $\mathrm{N}$ total tanah (Syofiani dan Islami, 2021). Pemberian bahan hijauan yang cepat melapuk dan memiliki kandungan $\mathrm{N}$ yang tinggi dapat sebagai sumber $\mathrm{N}$ yang efektif bagi tanaman (Gachengo et al. 1999). Bahan Kandungan unsur hara Nitrogen yang cukup tinggi pada kirinyuh cukup potensial untuk dimanfaatkan sebagai sumber bahan organik karna biomassanya tinggi. Dengan demikian pemberian air kelapa dan bokasi kirinyuh mungkin akan berpengaruh baik terhadap pertumbuhan tanaman sawi. Penelitian bertujuan untuk mengetahui pengaruh siraman air kelapa muda dan dosis bokashi kirinyuh terhadap pertumbuhan tanaman sawi.

\section{METODOLOGI PENELITIAN}

\section{Lokasi dan Waktu Penelitian}

Penelitian ini dilaksanakan di Laboratorium Lapangan I Fakultas Pertanian Universitas Halu Oleo (UHO) Kampus Hijau Bumi Tridharma Kendari, pada Bulan November 2019 sampai dengan Januari 2020.

\section{Bahan dan Alat}

Bahan yang digunakan dalam penelitian ini yaitu benih tanaman sawi varietas caisim, air kelapa muda, krinyuh, gula merah, efektif mikroorganisme 4 (EM4), polybag. Alat yang digunakan adalah alat ukur suhu (termometer), pengukur kelembaban tanah (Soil Moist PH Analyzer), sekop, ember, cangkul, parang, gergaji, martil, paku, tali, gembor, gelas ukur, selang, meteran, mistar, hand spayer, kertas label, patok label, paranet, pestisida, timbangan analitik, oven listrik, gunting, kamera dan alat tulis-menulis.

\section{Rancangan Penelitian}

Penelitian dilaksanakan dengan menggunakan Rancangan Acak Kelompok (RAK) yang disusun secara faktorial: Faktor I: pemberian air kelapa (A) yang terdiri dari tiga level yaitu: $\mathrm{A} 0=$ kontrol, $\mathrm{A} 1=$ air kelapa muda $100 \mathrm{ml} / \mathrm{tanaman}$, A2=air kelapa $150 \mathrm{ml} /$ tanaman, A3=air kelapa 200 $\mathrm{ml} /$ tanaman. Faktor II: takaran bokashi kirinyuh (K) yang terdiri dari tiga level yaitu: $\mathrm{K} 0=\mathrm{Kontrol}$, $\mathrm{K} 1=$ bokashi kirinyuh 7,5 $\mathrm{g}$ bokashi kirinyuh $\mathrm{kg}^{-1}$ tanah, $\mathrm{K} 2=10 \mathrm{~g}$ bokashi kirinyuh $\mathrm{kg}^{-1}$ tanah, $\mathrm{K} 3=12,5 \mathrm{~g}$ bokashi kirinyuh $\mathrm{kg}^{-1}$ tanah.

\section{Aplikasi Bokasi Krinyuh dan Air Kelapa}

Dalam proses penanaman tanaman sawi, bokashi kirinyuh sesuai dengan takaran yang dicobakan, dicampur merata dengan media $10 \mathrm{~kg}$ tanah pada setiap polybag. Pencampuran bokashi kirinyuh dan tanah dilakukan 1 minggu sebelum penanaman tanaman sawi. Sedangkan penyiraman air kelapa muda dilakukan setelah tanaman sawi berumur 7, 14, dan 21 hari setelah tanam (HST). Volume air kelapa yang digunakan ditakar pada gelar ukur sesuai masing-masing perlakuan.

\section{Variabel Pengamatan}

Variabel pengamatan dalam penelitian ini yaitu tinggi tanaman $(\mathrm{cm})$ yang diukur dari pangkal batang sampai ujung daun tertinggi, jumlah daun (helai) dihitung semua daun tanaman sawi yang telah terbuka sempurna, luas daun $\left(\mathrm{cm}^{2}\right)$ dihitung dengan mengukur panjang daun dan lebar daun, hasilnya dikalikan dengan konstanta $(0,78)$, dengan rumus : $\mathrm{L}=\mathrm{P} \times \mathrm{L} \times \mathrm{k}$, dimana $\mathrm{P}=$ Panjang; $\mathrm{L}=$ Lebar dan $\mathrm{k}=$ Koefisien luas daun. Nilai konstanta luas daun $(\mathrm{k}=0,7892)$ (Sitompul dan Guritno, 1995). Disamping itu diamati berat segar tajuk tanaman (g) dan berat segar akar (g), yang dilakukan dengan menimbang setelah tanaman dicabut secara hati-hati agar tanaman tidak rusak. Berat kering tajuk tanaman (g) dan berat kering akar tanaman $(\mathrm{g})$ dilakukan dengan menimbang bagian tajuk tanaman dan akar tanaman yang telah dikeringkan dengan menggunakan ovenkan pada suhu $80^{\circ} \mathrm{C}$ selama $2 \times 24$ jam.

\section{Analisis Data}

Data hasil pengamatan dianalisis dengan menggunakan analisis ragam atau ANOVA. Jika dalam hasil analisis menunjukan $\mathrm{F}_{\text {hitung }}>\mathrm{F}_{\text {tabel, }}$ maka dilanjutkann dengan Uji Jarak Berganda Duncan (UJBD) pada taraf nyata $=0,05$.

\section{HASIL DAN PEMBAHASAN}

Berdasarkan hasil penelitian
menunjukkan bahwa pemberian air kelapa
berpengaruh nyata secara mandiri terhadap
tinggi tanaman pada umur 16 HST dan 28 HST,
jumlah daun pada umur $16 \mathrm{HST}$, dan luas daun
pada umur 16 HST, tetapi berpengaruh tidak
nyata pada tinggi tanaman pada umur 10 dan 22


HST, jumlah daun luas daun pada umur 10, 22, dan 28 HST, berat segar tanaman, berat segar akar, berat kering tanaman dan berat kering akar tanaman sawi. Pada pemberian berbagai dosis bokasi kirinyuh berpengaruh sangat nyata terhadap tinggi tanaman, jumlah daun, luas daun pada umur 10, 16, 22, dan 28 HST, berat segar tanaman, berat segar akar, berat kering tanaman dan berat kering akar. Pengaruh interaksi pemberian air kelapa dan dosis bokashi kirinyuh berpengaruh tidak nyata terhadap pertumbuhan sawi.

\section{Tinggi Tanaman}

Air kelapa dan bokashi kirinyuh berpengaruh nyata terhadap tinggi tanaman sawi umur 10, 16, 22 dan 28 HST. UJBD pengaruh air kelapa muda terhadap rata-rata tinggi tanaman sawi umur 10, 16, 22 dan 28 HST disajikan pada Tabel 1. Tabel 1 menunjukkan bahwa rata-rata tinggi tanaman sawi umur tanaman 10, 16 dan 22 HST tertinggi diperoleh pada perlakuan A3 yang berbeda nyata dengan A0 tetapi tidak berbeda nyata dengan perlakuan lainnya, sedangkan rata-rata tinggi tanaman sawi umur 28 HST tertinggi diperoleh pada perlakuan A3 yaitu $11.46 \mathrm{~cm}$ berbeda nyata dengan A0 dan A1 tetapi tidak berbeda nyata dengan perlakuan A2. Perlakuan air kelapa $200 \mathrm{ml} /$ tanaman menunjukkan peningkatan tinggi tanaman pada umur 28 HST sebesar $30.88 \%$ dibanding kontrol. Hal ini menunjukkan bahwa air kelapa dapat mensupali kebutuhan hara tanaman guna mendukung pertumbuhan tanaman. Air kelapa memiliki kandungan komposisi kimia yang terdiri dari mineral, vitamin, gula, asam amino, dan fitohormon yang berpengaruh siginifikan terhadap pertumbuhan tanaman (Winarto et al. 2015). Peningkatan pertambahan tinggi tanaman juga dapat dipengaruhi oleh kandungan fitohormon seperti auksin dan sitokinin yang terkandung dalam air kelapa. Darlina et al. (2016) menyatakan bahwa air kelapa mengandung hormon giberelin, sitokinin, dan auksin serta senyawa lain yang dapat memacu pertumbuhan, sehingga dapat mempengaruhi pertumbuhan. Uuksin dan sitokinin berperanan dalam proses pembelahan sel sehingga membantu pertambahan tinggi dan tunas. Sitokinin memacu sel untuk membelah secara cepat dan auksin memacu sel untuk memanjang. Pembelahan sel yang dipacu oleh sitokinin dan pembesaran sel yang dipacu oleh auksin menyebabkan terjadinya pertumbuhan (Tiwery, 2014). Pemanjangan batang terjadi karena adanya proses pembelahan, pemanjangan dan pembesaran sel-sel baru yang mengakibatkan tanaman bertambah tinggi (Tuhuteru et al. 2012). Hal ini juga sesuai studi penggunaan air kelapa terhadap pertumbuhan tanaman bahwa pemberian air kelapa dapat meningkatkan pertumbuhan tanaman bawang merah (Nana dan Salamah, 2014).

UJBD pengaruh bokashi kirinyuh terhadap rata-rata tinggi tanaman sawi umur 10, 16, 22 dan 28 HST disajikan pada Tabel 2. Tabel 2 menunjukkan bahwa rata-rata tinggi tanaman sawi umur tanaman 10 dan 16 HST tertinggi diperoleh pada perlakuan $\mathrm{K} 3$ yang berbeda nyata dengan $\mathrm{K} 0$ dan $\mathrm{K} 1$ tetapi tidak berbeda nyata dengan perlakuan $\mathrm{K} 2$ dan $\mathrm{K} 3$, sedangkan rata-rata tinggi tanaman sawi umur 22 dan 28 HST tertinggi diperoleh pada perlakuan A3 yang berbeda nyata dengan perlakuan lainnya. Perlakuan 12,5 g bokashi kirinyuh $\mathrm{kg}^{-1}$ tanah menunjukkan peningkatan tinggi tanaman pada umur 28 HST sebesar $40.63 \%$ dibanding control.

Hal ini diduga karena bokashi kirinyuh tidak hanya menyediakan hara bagi tanaman seperti $\mathrm{N}, \mathrm{P}, \mathrm{K}$, tetapi juga mengandung bahan organik yang berperan dalam memperbaiki sifat-sifat tanah seperti sifat fisik, biologi, dan kimia tanah. Sifat fisik tanah berakibat pada aerasi menjadi lebih baik dan meningkatkan daya pegang air, sehingga air tersedia bagi tanaman. Jumila (2005) menyatakan bahwa komposisi hara kirinyuh memiliki $2.42 \% \mathrm{~N}$, $0.26 \%$ P $0,51 \%, 50.40 \%$ C dan $20.82 \% \quad \mathrm{C} / \mathrm{N}$. Pemberian kirinyuh berperan penting dalam meningkatkan $\mathrm{N}$ total tanah (Syofiani dan Islami, 2021). Menurut Sutedjo (2008) dalam Hapsari (2013) bahwa nitrogen merupakan hara utama bagi pertumbuhan tanaman, yang pada umumnya sangat diperlukan untuk pembentukan atau pertumbuhan bagian-bagian vegetatif tanaman. Pemberian bahan hijauan yang cepat melapuk dan memiliki kandungan $\mathrm{N}$ yang tinggi dapat sebagai sumber $\mathrm{N}$ yang efektif bagi tanaman (Gachengo et al. 1999). Kandungan hara yang cukup tinggi ini khususnya $\mathrm{N}$ akan mendukung pertambahan tinggi tanaman sawi. Proses fisiologi tanaman dalam berlangsung dengan baik jika unsur hara tersedia cukup bagi tanaman dan unsur hara yang paling banyak berperan untuk pertumbuhan dan perkembangan tanaman adalah nitrogen (N) (Sarief, 1989). Berperan penting dalam merangsang pertumbuhan vegetative tanaman yang ditandai dengan penambahan ukuran pada jumlah daun, luas daun dan tinggi tanaman. Selanjutnya oleh Suntoro (2001) menyatakan bahwa kandungan hara pupuk bokashi yaitu Nitrogen $7,76 \%$, Fosfor $1,10 \%$ dan Kalium $5,79 \%$ sehingga 
dapat meningkatkan pertumbuhan dan produksi tanaman sawi. Pemberian bokashi daun kirinyuh 20 ton/ha meningkatkan tinggi tanaman sawi $20,16 \%$ dibanding dengan tanpa bokashi daun kirinyuh (Suhda et al. 2016).

Tabel 1. Pengaruh air kelapa terhadap pertumbuhan tinggi $(\mathrm{cm})$ tanaman sawi

\begin{tabular}{lllll}
\hline \multirow{2}{*}{ Perlakuan } & \multicolumn{3}{c}{ Umur Tanaman } \\
\cline { 2 - 5 } Kontrol (A0) & $10 \mathrm{HST}$ & $16 \mathrm{HST}$ & $22 \mathrm{HST}$ & $28 \mathrm{HST}$ \\
Air Kelapa $100 \mathrm{ml} / \operatorname{tanaman}(\mathrm{b} 1)$ & $9.10^{\mathrm{ab}}$ & $10.63^{\mathrm{b}}$ & $11.71^{\mathrm{b}}$ & $16.66 \mathrm{c}$ \\
Air Kelapa $150 \mathrm{ml} / \operatorname{tanaman}(\mathrm{A} 2)$ & $9.75^{\mathrm{a}}$ & $11.11^{\mathrm{a}}$ & $13.73^{\mathrm{a}}$ & $20.03 \mathrm{~b}$ \\
Air Kelapa $200 \mathrm{ml} / \operatorname{tanaman}(\mathrm{A} 3)$ & $10.17^{\mathrm{a}}$ & $11.46^{\mathrm{a}}$ & $14.55^{\mathrm{a}}$ & $21.02 \mathrm{a}$
\end{tabular}

Keterangan: Angka-angka yang diikuti oleh huruf yang sama pada kolom yang sama berbeda tidak nyata berdasarkan Uji Jarak Berganda Duncan (UJBD) pada taraf $\alpha 0,05$.

Tabel 2. Pengaruh bokasi kirinyuh terhadap rata-rata tinggi tanaman sawi pada umur 10, 16, 22 dan 28 HST

\begin{tabular}{lcccc}
\hline \multirow{2}{*}{ Perlakuan } & \multicolumn{3}{c}{ Umur Tanaman } \\
\cline { 2 - 5 } & $10 \mathrm{HST}$ & $16 \mathrm{HST}$ & $22 \mathrm{HST}$ & $28 \mathrm{HST}$ \\
\hline Kontrol (K0) & $7.94 \mathrm{~b}$ & $8.30 \mathrm{c}$ & $9.74 \mathrm{~d}$ & $15.80 \mathrm{c}$ \\
$7,5 \mathrm{~g}$ bokashi kirinyuh $\mathrm{kg}^{-1} \operatorname{tanah}(\mathrm{K} 1)$ & $8.90 \mathrm{~b}$ & $10.86 \mathrm{~b}$ & $12.97 \mathrm{c}$ & $19.86 \mathrm{~b}$ \\
$10 \mathrm{~g}$ bokashi kirinyuh $\mathrm{kg}^{-1} \operatorname{tanah}(\mathrm{K} 2)$ & $10.02 \mathrm{a}$ & $11.67 \mathrm{ab}$ & $14.91 \mathrm{~b}$ & $20.63 \mathrm{~b}$ \\
12,5 g bokashi kirinyuh $\mathrm{kg}^{-1} \operatorname{tanah}(\mathrm{K} 3)$ & $10.67 \mathrm{a}$ & $12.16 \mathrm{a}$ & $16.15 \mathrm{a}$ & $22.22 \mathrm{a}$ \\
\hline
\end{tabular}

Keterangan: Angka-angka yang diikuti oleh huruf yang sama pada kolom yang sama berbeda tidak nyata berdasarkan Uji Jarak Berganda Duncan (UJBD) pada taraf $\alpha 0,05$.

\section{Jumlah Daun}

Air kelapa dan bokashi kirinyuh berpengaruh nyata terhadap jumlah daun tanaman sawi umur 10, 16, 22 dan 28 HST. UJBD pengaruh bokashi kirinyuh terhadap rata-rata jumlah daun tanaman sawi umur 10, 16, 22 dan 28 HST disajikan pada Tabel 3. Tabel 3 menunjukkan bahwa rata-rata jumlah daun tanaman sawi umur tanaman 10 dan 22 HST tertinggi diperoleh pada perlakuan A3 yang berbeda nyata dengan A0 tetapi tidak berbeda nyata dengan perlakuan lainnya. Demikian pula jumlah daun tanaman yang lebih rendah diperoleh pada A0 tetapi tidak berbeda nyata dengan perlakuan A1. Rata-rata jumlah daun tanaman sawi umur 28 HST tertinggi diperoleh pada perlakuan A3 yang berbeda nyata dengan perlakuan lainnya. Perlakuan air kelapa 200 $\mathrm{ml} /$ tanaman menunjukkan peningkatan jumlah daun tanaman sawi pada umur 28 HST sebesar $27.59 \%$ dibanding kontrol. Hal tersebut diduga karena pada air kelapa $200 \mathrm{ml} /$ tanaman terdapat cadangan hormon auksin, sitokinin dan ketersediaan nutrisi lebih baik yang dibutuhkan oleh tanaman jika dibandingkan dengan jumlah pemberian air kelapa muda pada perlakuan lainnya. Hal ini dimungkinkan oleh adanya stimulasi aktivitas sitokinin dan auksin yang dapat menginisiasi pembelahan dan pembesaran sel pada jaringan. Menurut Tiwery (2014) kandungan auksin dan sitokinin yang terdapat dalam air kelapa mempunyai peranan penting dalam proses pembelahan sel sehingga membantu pembentukan tunas. Pertumbuhan sel pada tanaman dirangsang oleh sitokinin, yang selanjutnya sel-sel yang membelah akan berkembang menjadi tunas, cabang dan daun (Tekei, 2001 dalam Oksana et al. 2012). Air kelapa berperan penting dalam proses pembentukkan dan pertumbuhan daun karena di dalam air kelapa terdapat hormon sitokinin yang mampu merangsang pembentukkan daun dengan baik (Nana dan Salamah, 2014).

UJBD pengaruh bokashi kirinyuh terhadap rata-rata jumlah daun tanaman sawi umur 10, 16, 22 dan 28 HST disajikan pada Tabel 4. Tabel 4 menunjukkan bahwa rata-rata jumlah daun tanaman sawi umur tanaman 10, 16 dan 22 HST tertinggi 
diperoleh pada perlakuan $\mathrm{K} 3$ yang berbeda nyata dengan K0 tetapi tidak berbeda nyata dengan perlakuan lainnya, sedangkan rata-rata jumlah daun tanaman sawi umur 28 HST tertinggi diperoleh pada perlakuan K3 yang berbeda nyata dengan perlakuan lainnya. Jumlah daun tanaman sawi yang lebih rendah diperoleh pada K0 dan berbeda nyata dengan perlakuan lainnya. Perlakuan $12,5 \mathrm{~g}$ bokashi kirinyuh $\mathrm{kg}^{-1}$ tanah menunjukkan peningkatan jumlah daun tanaman sawi pada umur 28 HST sebesar $30.39 \%$ dibanding control.

Bokashi mengandung mikroorganisma tanah efektif sebagai decomposer yang dapat mempercepat proses dekomposisi bahan organic dalam tanah, sehingga dapat meningkatkan ketersediaan unsur hara $\mathrm{N}, \mathrm{P}$ dan $\mathrm{K}$ bagi tanaman (Wang et al. 2012; Kaya, 2013). Disampin itu bahan organik berfungsi sebagai sumber bahan energi bagi mikroba dan merupakan salah satu komponen tanah yang sangat penting bagi ekosistem tanah, dimana bahan organik merupakan sumber dan pengikat hara dan sebagai substrat bagi mikroba tanah (Nugroho, 2013). Adanya kandungan hara kirinyuh memiliki $2.42 \% \mathrm{~N}, 0.26 \% \mathrm{P} 0,51 \%$, $50.40 \% \mathrm{C}$ dan $20.82 \% \mathrm{C} / \mathrm{N}$ (Jumila, 2005) akan memacu pertumbuhan dan perkembangan tanaman. Unsur $\mathrm{N}$ berfungsi merangsang pertumbuhan daun, menghijaukan daun serta mempertinggi kandungan protein (Sutejo et al. 1991). Hal ini juga sesuai studi oleh Suhda et al. (2016) bahwa pemberian bokashi daun kirinyuh 20 ton/ha meningkatkan jumlah daun tanaman sawi $23,46 \%$ dibanding dengan tanpa bokashi daun kirinyuh.

Tabel 3. Pengaruh air kelapa terhadap rata-rata jumlah daun (helai) tanaman sawi pada umur 10, 16, 22 dan 28 HST

\begin{tabular}{lrrrr}
\hline \multirow{2}{*}{ Perlakuan } & \multicolumn{4}{c}{ Umur Tanaman } \\
\cline { 2 - 5 } & $10 \mathrm{HST}$ & $16 \mathrm{HST}$ & $22 \mathrm{HST}$ & $28 \mathrm{HST}$ \\
\hline Kontrol (A0) & $3.75^{\mathrm{b}}$ & $4.64^{\mathrm{c}}$ & $5.37^{\mathrm{b}}$ & $7.72^{\mathrm{c}}$ \\
Air Kelapa Muda $100 \mathrm{ml}(\mathrm{A} 1)$ & $3.91^{\mathrm{ab}}$ & $4.85^{\mathrm{bc}}$ & $5.85^{\mathrm{ab}}$ & $8.83^{\mathrm{b}}$ \\
Air Kelapa Muda $150 \mathrm{ml}$ (A2) & $3.93^{\mathrm{ab}}$ & $5.00^{\mathrm{ab}}$ & $5.96^{\mathrm{a}}$ & $9.10^{\mathrm{b}}$ \\
Air Kelapa Muda $200 \mathrm{ml}(\mathrm{A} 3)$ & $4.10^{\mathrm{a}}$ & $5.23^{\mathrm{a}}$ & $6.02^{\mathrm{a}}$ & $9.85^{\mathrm{a}}$ \\
\hline
\end{tabular}

Keterangan: Angka-angka yang diikuti oleh huruf yang sama pada kolom yang sama berbeda tidak nyata berdasarkan Uji Jarak Berganda Duncan (UJBD) pada taraf $\alpha 0,05$.

Tabel 4. Pengaruh bokasi kirinyuh terhadap rata-rata jumlah daun (helai) tanaman sawi pada umur 10, 16, 22 dan 28 HST

\begin{tabular}{llrrr}
\hline \multirow{2}{*}{ Perlakuan } & \multicolumn{4}{c}{ Umur Tanaman } \\
\cline { 2 - 5 } & $10 \mathrm{HST}$ & $16 \mathrm{HST}$ & $22 \mathrm{HST}$ & $28 \mathrm{HST}$ \\
\hline Kontrol (K0) & $3.45 \mathrm{~b}$ & $4.17 \mathrm{~b}$ & $4.99 \mathrm{~b}$ & $7.60 \mathrm{c}$ \\
$7,5 \mathrm{~g}$ bokashi kirinyuh $\mathrm{kg}^{-1} \operatorname{tanah}(\mathrm{K} 1)$ & $4.04 \mathrm{a}$ & $5.10 \mathrm{a}$ & $5.91 \mathrm{a}$ & $8.85 \mathrm{~b}$ \\
$10 \mathrm{~g}^{-1}$ bokashi kirinyuh $\mathrm{kg}^{-1}$ tanah (K2) & $4.10 \mathrm{a}$ & $5.18 \mathrm{a}$ & $6.10 \mathrm{a}$ & $9.14 \mathrm{~b}$ \\
12,5 g bokashi kirinyuh $\mathrm{kg}^{-1}$ tanah (K3) & $4.10 \mathrm{a}$ & $5.27 \mathrm{a}$ & $6.20 \mathrm{a}$ & $9.91 \mathrm{a}$ \\
\hline
\end{tabular}

Keterangan: Angka-angka yang diikuti oleh huruf yang sama pada kolom yang sama berbeda tidak nyata berdasarkan Uji Jarak Berganda Duncan (UJBD) pada taraf $\alpha 0,05$.

\section{Luas Daun}

Air kelapa dan bokashi kirinyuh berpengaruh nyata terhadap luas daun tanaman sawi umur 10, 16, 22 dan 28 HST. UJBD pengaruh bokashi kirinyuh terhadap rata-rata luas daun tanaman sawi umur 10, 16, 22 dan 28 HST disajikan pada Tabel 5. Tabel 5 menunjukkan bahwa rata-rata luas daun tanaman sawi umur tanaman 10,16 dan 22 HST tertinggi diperoleh pada perlakuan $\mathrm{A} 3$ yang berbeda nyata dengan $\mathrm{A} 0$ dan A1 tetapi tidak berbeda nyata dengan perlakuan A1 dan A0. Demikian pula luas daun tanaman yang lebih rendah diperoleh pada A0 tetapi tidak berbeda nyata dengan perlakuan A1. Rata-rata luas daun 
tanaman sawi umur 28 HST tertinggi diperoleh pada perlakuan A3 yang berbeda nyata dengan perlakuan lainnya, dan rata-rata luas daun lebih rendah juga diperoleh pada $\mathrm{A} 0$ dan berbeda nyata dengan perlakuan lainnya. Perlakuan air kelapa 200 $\mathrm{ml} /$ tanaman menunjukkan peningkatan luas daun tanaman sawi pada umur 28 HST sebesar 56.96\% dibanding kontrol.

Perkembangan luas daun diduga dipengaruhi oleh konsentrasi air kelapa muda yang diberikan, dimana dengan adanya peningkatan konsentrasi zat pengatur tumbuh (ZPT) alami yang diberikan menghasilkan luasan daun tanaman sawi yang semakin meningkat. Keadaan tersebut dikaitan dengan kandungan hara dan hormon dalam air kelapa sebagai ZPT alami. Hal ini sesuai dengan yang dilaporkan oleh Rosniawaty et al. (2018) bahwa air kelapa mengandung 0,0039\% hormon auksin, $0,0017 \%$ hormon sitokinin, 0,0018 hormon giberelin. Auksin berperan dalam meregulasi produksi hormon untuk memacu pembelahan sel dan pembentukan tunas baru yang berpengaruh terhadap jumlah dan luas daun. Semakin besar luas daun maka semakin banyak hasil fotosintesis karena akan bertambah per satuan luas daun (Dewi danTambingsila, 2014).

UJBD pengaruh bokashi kirinyuh terhadap rata-rata luas daun tanaman sawi umur $10,16,22$ dan 28 HST disajikan pada Tabel 6. Tabel 6 menunjukkan bahwa rata-rata luas daun tanaman sawi umur tanaman 10 HST tertinggi diperoleh pada perlakuan $\mathrm{K} 3$ yang berbeda nyata dengan $\mathrm{K} 0$ tetapi tidak berbeda nyata dengan perlakuan lainnya, sedangkan rata-rata luas daun tanaman sawi umur 16 dan 22 HST tertinggi diperoleh pada perlakuan $\mathrm{K} 3$ yang berbeda nyata dengan perlakuan K0 dan K1 tetapi tidak berbeda nyata dengan K2 . Rata-rata luas daun tanaman sawi tertinggi umur tanaman 28 HST diperoleh pada K3 dan berbeda nyata dengan perlakuan lainnya, sedangkan rata-rata luas daun lebih rendah umur 10,16,22 dan 28 HST diperoleh pada K0. Perlakuan 12,5 g bokashi kirinyuh $\mathrm{kg}^{-1}$ tanah menunjukkan peningkatan luas daun tanaman sawi pada umur 28 HST sebesar $74.91 \%$ dibanding control. Hal ini menunjukkan bahwa semakin tinggi dosis bokashi kirinyu dapat menyediakan unsur hara seperti N, P dan K yang cukup untuk pertumbuhan daun tanaman sawi. Nitrogen memiliki peranan penting untuk meningkatkan pertumbuhan bagian vegetative tanaman seperti pertumbuhan daun tanaman (Lingga dan Marsono, 2008). Nitrogen merupakan bagian penyusun protein, protoplasma dan pembentuk bagian tanaman seperti batang dan daun yang merupakan tempat aktivitas fotosintensis. Menurut Ninja et al. (2012), semakin luas permukaan daun maka intensitas sinar matahari yang diterima semakin besar, dan klorofil pada daun yang berfungsi menangkap energi matahari akan meningkatkan laju fotosintesis sehingga semakin banyak karbohidrat yang dihasilkan untuk pembelahan sel dan menyebabkan daun tumbuh lebih besar dan lebar, sehingga berpengaruh terhadap berat segar bagian atas tanaman. Studi lain menunjukkan bahwa pemberian bokashi daun kirinyuh 20 ton/ha meningkatkan luas daun tanaman sawi 32,39\% dibanding dengan tanpa bokashi daun kirinyuh (Suhda et al. 2016).

Tabel 5. Pengaruh air kelapa terhadap rata-rata luas daun $\left(\mathrm{cm}^{2}\right)$ tanaman sawi pada umur $10,16,22$ dan 28 HST

\begin{tabular}{lllll}
\hline \multirow{2}{*}{ Perlakuan } & \multicolumn{3}{c}{ Umur Tanaman } \\
\cline { 2 - 5 } & $10 \mathrm{HST}$ & $16 \mathrm{HST}$ & $22 \mathrm{HST}$ & $28 \mathrm{HST}$ \\
\hline Kontrol (A0) & $6.16^{\mathrm{b}}$ & $9.28^{\mathrm{b}}$ & $16.36^{\mathrm{b}}$ & $54.46^{\mathrm{d}}$ \\
Air Kelapa $100 \mathrm{ml} / \operatorname{tanaman}(\mathrm{A} 1)$ & $6.77^{\mathrm{b}}$ & $10.07^{\mathrm{b}}$ & $18.51^{\mathrm{b}}$ & $64.13^{\mathrm{c}}$ \\
Air Kelapa $150 \mathrm{ml} / \operatorname{tanaman}(\mathrm{A} 2)$ & $8.72^{\mathrm{a}}$ & $12.55^{\mathrm{ab}}$ & $20.45^{\mathrm{ab}}$ & $74.27^{\mathrm{b}}$ \\
Air Kelapa $200 \mathrm{ml} / \operatorname{tanaman}(\mathrm{A} 3)$ & $8.87^{\mathrm{a}}$ & $16.16^{\mathrm{a}}$ & $26.60^{\mathrm{a}}$ & $85.48^{\mathrm{a}}$
\end{tabular}

Keterangan: Angka-angka yang diikuti oleh huruf yang sama pada kolom yang sama berbeda tidak nyata berdasarkan Uji Jarak Berganda Duncan (UJBD) pada taraf $\alpha 0,05$.

\section{Berat segar dan berat kering akar tanaman}

Air kelapa tidak berpengaruh nyata terhadap berat segar dan berat kering akar tanaman sawi umur 10, 16, 22 dan 28 HST sedangkan bokashi kirinyuh juga tidak berpengaruh nyata terhadap berat segar dan berat kering akar tanaman umur tanaman 10,16 dan 22 HST tetapi bokashi kirinyuh berpengaruh nyata terhadap berat segar 
dan berat kering akar tanaman sawi umur tanaman 28 HST. UJBD pengaruh bokashi kirinyuh terhadap berat segar dan berat kering akar tanaman sawi umur 10, 16, 22 dan 28 HST disajikan pada Tabel 7 dan 8 . Tabel 7 dan 8 menunjukkan bahwa rata-rata berat segar dan berat kering akar tanaman sawi tertinggi umur tanaman 28 HST diperoleh pada perlakuan $\mathrm{K} 3$ yang berbeda nyata dengan $\mathrm{K} 0$ dan $\mathrm{K} 1$ tetapi tidak berbeda nyata dengan perlakuan $\mathrm{K} 2$, sedangkan rata-rata berat segar dan berat kering akar tanaman sawi lebih rendah diperoleh pada K0 dan berbeda nyata dengan perlakuan lainnya. Perlakuan 12,5 g bokashi kirinyuh $\mathrm{kg}^{-1}$ tanah menunjukkan peningkatan berat segar dan berat kering akar tanaman sawi pada umur 28 HST masing-masing sebesar $311.22 \%$ dan $325.93 \%$ dibanding kontrol.

Hal ini menunjukan bahwa semakin tinggi dosis pupuk akan memberikan pengaruh positif terhadap pertumbuhan dan perkembangan akar tanaman sawi. Kandungan hara kirinyuh memiliki $2.42 \% \mathrm{~N}, 0.26 \%$ P $0,51 \%, 50.40 \% \mathrm{C}$ dan $20.82 \%$ $\mathrm{C} / \mathrm{N}$ (Jumila, 2005). Keberadaan unsur hara khususnya hara $\mathrm{P}$ akan mendukung pertumbuhan akar tanaman sawi. Adetias (2017) mengatakan, unsur $\mathrm{P}$ berperan penting dalam transfer energi dalam sel tanaman dan dapat juga meningkatkan efisiensi dari produksi suatu tanaman. Fosfor diperlukan tanaman sebagai penyusun asam nukleat dan perkembangan jaringan meristem serta merangsang pertumbuhan akar. Nitrogen memiliki peranan penting untuk meningkatkan pertumbuhan bagian vegetative tanaman antara lain mendukung pertumbuhan akar tanaman (Lingga dan Marsono, 2008). Selanjutnya dijelaskan bahwa bobot kering menunjukkan kemampuan tanaman dalam mengambil unsur hara dari media tanam untuk menunjang pertumbuhannya, bobot kering merupakan indikasi keberhasilan pertumbuhan tanaman, karena bobot kering merupakan petunjuk adanya hasil fotosintesis bersih yang dapat diendapkan setelah kadar airnya dikeringkan. Menurut Ardiansyah (2013), menyatakan bahwa hasil berat kering merupakan keseimbangan antara fotosintesis dan respirasi. Pemberian bokashi daun kirinyuh 20 ton/ha meningkatkan berat akar tanaman sawi 64,12\% dibanding dengan tanpa bokashi daun kirinyuh (Suhda et al. 2016).

Tabel 6. Pengaruh bokasi kirinyuh terhadap rata-rata luas daun $\left(\mathrm{cm}^{2}\right)$ tanaman sawi pada umur $10,16,22$ dan 28 HST

\begin{tabular}{lcccc}
\hline \multirow{2}{*}{ Perlakuan } & \multicolumn{3}{c}{ Umur Tanaman } \\
\cline { 2 - 5 } & $10 \mathrm{HST}$ & $16 \mathrm{HST}$ & $22 \mathrm{HST}$ & $28 \mathrm{HST}$ \\
\hline Kontrol (K0) & $5.54^{\mathrm{b}}$ & $6.70^{\mathrm{c}}$ & $11.23^{\mathrm{c}}$ & $49.18^{\mathrm{c}}$ \\
$7,5 \mathrm{~g}$ bokashi kirinyuh $\mathrm{kg}^{-1} \operatorname{tanah}(\mathrm{K} 1)$ & $8.11^{\mathrm{a}}$ & $11.08^{\mathrm{b}}$ & $20.15^{\mathrm{b}}$ & $70.39^{\mathrm{b}}$ \\
$10 \mathrm{~g}$ bokashi kirinyuh $\mathrm{kg}^{-1} \operatorname{tanah}(\mathrm{K} 2)$ & $8.26^{\mathrm{a}}$ & $14.05^{\mathrm{ab}}$ & $22.50^{\mathrm{ab}}$ & $72.75^{\mathrm{b}}$ \\
$12,5 \mathrm{~g}$ bokashi kirinyuh $\mathrm{kg}^{-1} \operatorname{tanah}(\mathrm{K} 3)$ & $8.62^{\mathrm{a}}$ & $16.23^{\mathrm{a}}$ & $28.04^{\mathrm{a}}$ & $86.02^{\mathrm{a}}$ \\
\hline
\end{tabular}

Keterangan: Angka-angka yang diikuti oleh huruf yang sama pada kolom yang sama berbeda tidak nyata berdasarkan Uji Jarak Berganda Duncan (UJBD) pada taraf $\alpha 0,05$.

Tabel 7. Pengaruh bokasi kirinyuh terhadap rata-rata berat segar akar (g) tanaman sawi pada umur 28 HST

\begin{tabular}{lc}
\hline Perlakuan & Umur Tanaman \\
\hline Kontrol (K0) & $28 \mathrm{HST}$ \\
$7,5 \mathrm{~g}$ bokashi kirinyuh $\mathrm{kg}^{-1} \operatorname{tanah}(\mathrm{K} 1)$ & $1.96 \mathrm{c}$ \\
$10 \mathrm{~g}^{-1}$ bokashi kirinyuh $\mathrm{kg}^{-1} \operatorname{tanah~(K2)}$ & $4.55 \mathrm{~b}$ \\
$12,5 \mathrm{~g}$ bokashi kirinyuh $\mathrm{kg}^{-1} \operatorname{tanah}(\mathrm{K} 3)$ & $6.93 \mathrm{ab}$ \\
\hline
\end{tabular}

Keterangan: Angka-angka yang diikuti oleh huruf yang sama pada kolom yang sama berbeda tidak nyata berdasarkan Uji Jarak Berganda Duncan (UJBD) pada taraf $\alpha 0,05$. 
J. Berkala Penelitian Agronomi 9 (2) : 75 - 86 (2021)

Tabel 8. Pengaruh bokasi kirinyuh terhadap rata-rata berat kering akar $(\mathrm{g})$ tanaman sawi pada umur $28 \mathrm{HST}$

\begin{tabular}{lc}
\hline Perlakuan & Umur Tanaman \\
\hline Kontrol (K0) & 28 HST \\
$7,5 \mathrm{~g}$ bokashi kirinyuh $\mathrm{kg}^{-1} \operatorname{tanah}(\mathrm{K} 1)$ & $1.08^{\mathrm{c}}$ \\
$10 \mathrm{~g}$ bokashi kirinyuh $\mathrm{kg}^{-1} \operatorname{tanah}(\mathrm{K} 2)$ & $2.54^{\mathrm{b}}$ \\
$12,5 \mathrm{~g}$ bokashi kirinyuh $\mathrm{kg}^{-1} \operatorname{tanah}(\mathrm{K} 3)$ & $4.15^{\mathrm{a}}$ \\
\hline
\end{tabular}

Keterangan: Angka-angka yang diikuti oleh huruf yang sama pada kolom yang sama berbeda tidak nyata berdasarkan Uji Jarak Berganda Duncan (UJBD) pada taraf $\alpha 0,05$.

\section{Berat segar dan berat kering tanaman}

Air kelapa tidak berpengaruh nyata terhadap berat segar dan berat kering tanaman umur 10, 16, 22 dan 28 HST sedangkan bokashi kirinyuh juga tidak berpengaruh nyata terhadap berat segar dan berat kering tanaman umur tanaman 10,16 dan 22 HST tetapi bokashi kirinyuh berpengaruh nyata terhadap berat segar dan berat kering tanaman sawi umur tanaman 28 HST. UJBD pengaruh bokashi kirinyuh terhadap berat segar tanaman sawi umur 10, 16, 22 dan 28 HST disajikan pada Tabel 9 dan 10. Tabel 9 dan 10 menunjukkan bahwa rata-rata berat segar dan kering tanaman sawi tertinggi umur tanaman 28 HST diperoleh pada perlakuan K3 yang berbeda nyata dengan K0 dan K1 tetapi tidak berbeda nyata dengan perlakuan K2, sedangkan rata-rata berat segar dan kering tanaman sawi lebih rendah diperoleh pada K0 dan tidak berbeda nyata dengan K1. Perlakuan 12,5 $\mathrm{g}$ bokashi kirinyuh $\mathrm{kg}^{-1}$ tanah menunjukkan peningkatan berat segar dan berat kering akar tanaman sawi pada umur 28 HST masing-masing sebesar $390.10 \%$ dan $224.17 \%$ dibanding kontrol.

Tabel 9. Pengaruh bokasi kirinyuh terhadap rata-rata berat segar tanaman sawi (g) pada umur 28 HST

\begin{tabular}{lc}
\hline Perlakuan & Umur Tanaman \\
\cline { 2 - 2 } Kontrol (K0) & $28 \mathrm{HST}$ \\
$7,5 \mathrm{~g}$ bokashi kirinyuh $\mathrm{kg}^{-1} \operatorname{tanah}(\mathrm{K} 1)$ & $3.84 \mathrm{~b}$ \\
$10 \mathrm{~g}$ bokashi kirinyuh $\mathrm{kg}^{-1} \operatorname{tanah}(\mathrm{K} 2)$ & $8.50 \mathrm{~b}$ \\
12,5 g bokashi kirinyuh $\mathrm{kg}^{-1}$ tanah (K3) & $16.47 \mathrm{a}$ \\
\hline
\end{tabular}

Keterangan: Angka-angka yang diikuti oleh huruf yang sama pada kolom yang sama berbeda tidak nyata berdasarkan Uji Jarak Berganda Duncan (UJBD) pada taraf $\alpha 0,05$.

Tabel 10. Pengaruh bokasi kirinyuh terhadap rata-rata berat kering tanaman sawi (g) pada umur 28 HST

\begin{tabular}{lc}
\hline Perlakuan & Umur Tanaman \\
\cline { 2 - 2 } Kontrol (K0) & $28 \mathrm{HST}$ \\
$7,5 \mathrm{~g}$ bokashi kirinyuh $\mathrm{kg}^{-1} \operatorname{tanah}(\mathrm{K} 1)$ & $3.31^{\mathrm{b}}$ \\
$10 \mathrm{~g}$ bokashi kirinyuh $\mathrm{kg}^{-1} \operatorname{tanah}(\mathrm{K} 2)$ & $5.05^{\mathrm{b}}$ \\
$12,5 \mathrm{~g}$ bokashi kirinyuh $\mathrm{kg}^{-1} \operatorname{tanah}(\mathrm{K} 3)$ & $9.83^{\mathrm{a}}$ \\
\hline
\end{tabular}

Keterangan: Angka-angka yang diikuti oleh huruf yang sama pada kolom yang sama berbeda tidak nyata berdasarkan Uji Jarak Berganda Duncan (UJBD) pada taraf $\alpha 0,05$. 
Hal ini menunjukkan bahwa semakin tinggi dosis pemberian bokasi kirinyuh semakin tinggi berat segar dan kering tanaman yang dihasilkan. Semakin tinggi dosis pupuk bokashi kirinyuh akan meningkatkan ketersediaan unsur hara NPK yang dapat meningkatkan pertumbuhan vegetatif tanaman. Pemberian kompos kirinyuh dengan dosis $20 \mathrm{t} / \mathrm{ha}$ meningkatkan sifat kimia tanah, $\mathrm{pH}, \mathrm{Al}-\mathrm{dd}$, P-tersedia, N-total, K-dd, dan memberikan terbaik terhadap pertumbuhan tanaman (Syofiani dan Islami, 2021). Menurut Darwin (2012) ketersediaan unsur hara berperan penting sebagai sumber energi sehingga tingkat kecukupan hara berperan dalam mempengaruhi biomassa dari suatu tanaman. Nitrogen memiliki peranan penting untuk meningkatkan pertumbuhan bagian vegetative tanaman antara lain untuk seperti pertumbuhan daun dan batang tanaman (Lingga dan Marsono, 2008). Pada Tabel 4 dan 5 menunjukkan bahwa semakin tinggi dosis pupuk bokashi kirinyuh mengahsilkan jumlah dan luas daun yang lebih tinggi. Hal ini mengindikasikan adanya peningkatan area tempat berlangsungnya proses fotosintensisi sehingga hasil fotosintat tiap satuan luas daun akan dapat meningkatkan berat kering tanaman sawi. Adanya peningkatan proses fotosintesis akan meningkatkan pula hasil fotosintesis berupa senyawa-senyawa organik yang akan ditranslokasikan ke seluruh organ tanaman dan berpengaruh terhadap berat kering tanaman. Nurdin (2011) mengatakan jumlah daun dapat berpengaruh terhadap peningkatan bobot kering tanaman karena daun merupakan tempat akumulasi hasil fotosintat tanaman. Suhda et al. (2016) melaporkan bahwa pemberian bokashi daun kirinyuh 20 ton/ha meningkatkan berat segar tanaman sawi 56,76\% dibanding dengan tanpa bokashi daun kirinyuh.

\section{KESIMPULAN}

Berdasarkan hasil penelitian maka dapat disimpulkan:

1. Air kelapa berpengaruh terhadap tinggi tanaman, jumlah daun dan luas daun tanaman sawi. Perlakuan air kelapa $200 \mathrm{ml} /$ tanaman meningkatkan tinggi tanaman, jumlah daun dan luas daun masing-masing $30.88 \%$, 27,59\% dan $56.96 \%$ dibanding dengan kontrol pada umur 28 hari setelah tanam.

2. Bokashi kirinyuh berpengaruh terhadap tinggi tanaman, jumlah daun, luas daun, berat segar dan kering akar serta berat segar dan berat kering tanaman sawi. Perlakuan 12,5 g bokashi kirinyuh $\mathrm{kg}^{-1}$ tanah meningkatkan tinggi tanaman, jumlah daun, luas daun, berat segar akar, berat kering akar, berat segar tanaman dan berat kering tanaman sawi masing-masing $40.63 \%, 30,39,74.91 \%, 311.22 \%, 325.93 \%$, $390.10 \%$ dan $224.17 \%$ dibanding dengan kontrol pada umur 28 hari setelah tanam.

\section{REFERENSI}

Adetias, G.K. 2017. Pengaruh Pemberian Nitrogen dan Fosfor Terhadap Pertumbuhan Legum Calopogonium mucunoides, Centrosema pubescens dan Arachis pintoi. https://repository.unja.ac.id/849/2/JURNAL $\% 20$ ADETIAS\%20KATANAKAN\%20GIN TING\%20\%28E10013243\%29.pdf

Ardiansyah, M. 2013. Respons Pertumbuhan dan Produksi Kedelai Hasil Seleksi Terhadap Pemberian Asam Askorbat dan Inokulasi Fungi Mikoriza Arbuskulardi Tanah Salin. Universitas Sumatera Utara, Medan. https://www.neliti.com/id/publications/9921 9/respons-pertumbuhan-dan-produksikedelai-hasil-seleksi-terhadap-pemberianasam-a

Badan Pusat Statistik (BPS). 2019. Sulawesi Tenggara (Sultra) Dalam Angka BPS (Edisi 31 Desember 2019).Kendari.

https://sultra.bps.go.id/publication/2019/08/ 16/7559ff8d4f67e0eeadf2be1c/provinsisulawesi-tenggara-dalam-angka-2019.html

Darlina, Hasanuddin, dan Rahmatan, H. 2016. Pengaruh Penyiraman Air Kelapa Terhadap Pertumbuhan Vegetatif Lada. Pendidikan Biologi, FKIP Unsyiah.

https://ejournal.unipas.ac.id/index.php/Agro /article/view/548/447

Darmawan, 2009. Budidaya Tanaman Sawi. Kanisius Yogyakarta.

Darwin H.P. 2012. Pengaruh Pupuk Organik Cair Terhadap Pertumbuhan dan Produksi Sayuran Daun Kangkung, Bayam dan Caisim. Procid. Sem. Nas. Perhimpunan Hortikultura Indonesia.

https://semnasagrotek.uinsgd.ac.id/index.ph $\mathrm{p} / \mathrm{semnas} /$ article/view/140

Dewi, E.S., dan Tambingsila, M. 2014. Kajian Peningkatan Serapan NPK Pada Pertumbuhan dan Hasil Tanaman Jagung Dengan Pemberian Kombinasi Pupuk 
anorganik Majemuk dan Berbagai Pupuk Organik. Jurnal Ilmiah AgroPet, 11 (1):46-57.

Gachengo, C.N., Palm, C.A., Jama, B.A dan Othieno, C. 1999. Tithonia and Sauna Green Manures and Inorganik Fertilization as Phosphorus Sources for Maize in Western Kenya, Agroforestry System, 44:21-36.

Hapsari, N. 2013. Pengaruh Pemberian Pupuk Cair Azolla sp Terhadap Serapan Nitrogen, Phospor, Biomassa, Kering dan Percepatan Pembungaan Tanaman Mentimun (Cucumis sativa $\mathrm{L}$.).

http://repository.unmuhjember.ac.id/1617/1/J URNAL.pdf

Haryanto, E., Suhartini, T., Rahayu, E., dan Sunarjo. 2006. Sawi dan Selada. Penebar Swadaya, Jakarta.

Jamilah, 2005. Potensi Gulma C. odorata Sebagai Pupuk Hijau Dibandingkan G. sepium Yang Diberi CMA Pada Lahan Marginal. Prosiding Kongres Nasional HITI VIII Tanggal 21-23 Juli 2003. Bandung

Kaya, E. 2013. Pengaruh Kompos Jerami dan Pupuk NPK Terhadap N Tersedia Tanah, Serapan N, Pertumbuhan dan Hasil Padi Sawah (Oryza sativa L.). Agrologia. 2(1):43-50.

Lingga dan Marsono, 2008. Petunjuk Penggunaan Pupuk. Penebar Swadaya, Jakarta

Maftu'ah, E., Asikin, S., dan Najib, M. 2005. Potensi Gulma Cromolaena odorata dan Ageratum conyzoydes Sebagai Sumber Pupuk N dan P Untuk Menuju Sistem Pertanian Organik. Prosiding Konferensi Nasional XVII. Himpunan Gulma Indonesia (HIGI) Yogyakarta.

Nana, S.A., dan Salamah, Z. 2014. Pertumbuhan Tanaman Bawang Merah (Allium cepa L.) Dengan Penyiraman Air Kelapa (Cocos nucifera L.) Sebagai Sumber Belajar Biologi SMA Kelas XII JUPEMASI-PBIO, 1 (1):82-86.

Ninja, Wasi'an, dan Santoso, E. 2012. Respons Tanaman Kailan Terhadap Pupuk Bokashi Jerami Padi Pada Tanah Aluvial. Jurnal Sains Mahasiswa Pertanian, 1(1):1-5.

Nugroho, A. K. (2013). Penggunaan Campuran Air Kelapa dan BAP (Benzil Amino Purin) pada Perbanyakan Tanaman Pisang Ambon (Musa paradisiaca) secara In-Vitro. Skripsi.
Universitas Islam Riau. Pekanbaru. https://core.ac.uk/download/pdf/141858529.pdf

Nurdin. 2011. Penggunaan Lahan Kering di Das Limboto Provinsi Gorontalo untuk Pertanian Berkelanjutan. Jurnal Litbang Pertanian 30(3): $98-107$.

http://ejurnal.litbang.pertanian.go.id/index.ph p/jppp/article/view/3453

Oksana, Rahmadani, E., dan Syamsul. 2012. Peranan Berbagai Macam Media Tumbuh Bagi Pertumbuhan Stek Daun Jeruk J.C. (Japance citroen) Dengan Beberapa Konsentrasi BAP. Jurnal Agroteknologi, 2(2):15-20.

Rosniawaty, S., Anjarsari, I.R.D., dan Sudirja, R. 2018. Aplikasi Sitokinin Untuk Meningkatkan Pertumbuhan Tanaman Teh di Dataran Rendah, Journal of Industrial and Beverage Crops, 5(1):31-38.

Rukmana, R. 2005. Bertanam Sawi dan Petsai. Jakarta: Penebar Swadaya.

Sarief, E.S. 1989. Fisika Kimia Tanah Pertanian. Pustaka Buana. Bandung

Sitompul, N.M., dan Guritno, B. 1995. Analisis Pertumbuhan Tanaman. Gadjah Mada University Press.

Syofiani, R dan Islami, S. 2021. Pengaruh Berbagai Dosis Kompos Kirinyuh (Chromolaena odorata) Terhadap Sifat Kimia Tanah dan Hasil Tanaman Jagung (Zea mays L.). Jurnal Agrium, 18 (1):52-56.

Suhda, F.L., Matatula, A.J., dan Makaruku, M.H. 2016. Pengaruh Dosis Bokashi Daun Krinyu (Chromolaena odorata) Terhadap Pertumbuhan dan Produksi Tanaman Sawi (Brassica juncea L.). J. Budidaya Pertanian, 12(2):108-111.

Tiwery, R.R. 2014. Pengaruh Penggunaan Air Kelapa terhadap Pertumbuhan Tanaman Sawi. Dalam Biopendix, 1(1): 83-91. http://www.jim.unsyiah.ac.id/pendidikanbiologi/article/view/309/305.

Tuhuteru, S., Hehanusa, M.L., dan Raharjo, S.H.T. 2012. Pertumbuhan dan Perkembangan Anggrek Dendrobium Anosmum Pada Media Kultur In Vitro Dengan Beberapa Konsentrasi Air Kelapa, Jurnal Agrologia 1(1):1-12. 
J. Berkala Penelitian Agronomi 9 (2) : 75 - 86 (2021)

Winarto, Budi, da Silva, Jaime, A., dan Teixeira. 2015. Use of Coconut Water and Fertilizer for Invitro Proliferation and Plantlet
Producution of Dendrobium 'Gradita 3' In Vitro Cell. Dvelopment Biology Journal, 51:303-314. 